\title{
LA RELACIÓN METAL-MUERTE EN LOS POEMAS DE GARCÍA LORCA
}

Decía una vez García Lorca que en España "lo más importante de todo tiene un último valor metálico de muerte" ("Teoría y juego del duende": VII, 149) ${ }^{1}$. Muerte y metal aparecen asociados a lo largo de su obra poética: bajo forma de sutiles y tímidas sugerencias en el Libro de poemas (1921), con más precisión en los puñales de Poema del cante jondo (1921), extendidos a nuevas zonas de objetos (cicutas, ortigas, pitas, peñascos) en el Romancero gitano (1927), dolorosamente agudizados en Poeta en Nueva York (1929-3o), hasta llegar a ser símbolo de España en el Llanto por Ignacio Sánchez Mejias $(1935)^{2}$.

Desde el comienzo ${ }^{3}$, la muerte domina aún en aquellos poemas en que más parece triunfar la vida - el mismo mes de abril "llena con nidos de oro / las floridas calaveras" ("Canción primaveral", en Libro de poemas: II, 28)-, y ya la imagen del metal alterna rítmicamente con otras de profundo tono dramático:

\author{
Esquilones de plata \\ llevan los bueyes. \\ Mi corazón desangra \\ como una fuente.
}

Los esquilones de 1919 se convertirán en "los sones de bordón" de "las terribles cinco de la tarde" (Llanto: IV, 152-153).

En estos primeros poemas la relación metal-muerte no está todavía clara. "Tremolar plateado de alas" ("Santiago" en Libro de poemas: II, 49), temblor del "farolito de la calle" ("Sorpresa", en Poema del cante jondo: $\mathrm{IV}, 86$ ), "metálicas gotas" del "insecto del tiempo" ("Consulta", en Libro de poemas: II, 82) son metáforas que anuncian

1 Citaré siempre por la edición de Obras completas de García Lorca, Losada, Buenos Aires, 3" ed., 1942, con indicación de volumen y de página.

${ }^{2}$ No me detengo especialmente en el Diván de Tamarit, pues no se manifiesta en este libro gran novedad por lo que toca al simbolo que me ocupa.

3 Entiendo por "primer período" el que comprende: Libro de poemas (1918. 1921), Primeras canciones (1922), Canciones (1921-1924) y Poema del cante jondo (1921). 
el desarrollo más exacto del tema en poemas posteriores. Tan sólo en una ocasión, en la "Elegía a doña Juana la Loca" (1918) (Libro de poemas: II, 30), al mencionar por primera vez el puñal -lo hiriente y homicida por excelencia-, precisa García Lorca la imagen que habrá de constituir después el centro de su grupo de metáforas metálicas:

Tenías la pasión que da el cielo de España.

La pasión del puñal, de la oreja y el llanto.

Más precisa aún se muestra la relación metal-muerte en los poemas esquemáticos, inmediatos, de sencilla construcción sintáctica, del Poema del cante jondo (1921). En este libro ya no domina lo vago como en los Primeros poemas o en las Canciones. La escueta precisión de los poemas aclara por completo el sentido mortal de los metales.

Temas de carácter religioso que García Lorca expresará más tarde en su obra se nos presentan en las cinco llagas de la guitarra ("las cinco llagas de Cristo / cortadas en Almería" del romance "La monja gitana"). Así dice en "La guitarra" (IV, 75):

\section{¡Oh guitarra! \\ Corazón malherido \\ por cinco espadas.}

La muerte-puñal que penetra en la carne ("el puñal / entra en el corazón / como la reja del arado / en el yermo", "Puñal": IV, 83) inicia en Poema del cante jondo un tema fecundo que seguirá desarrollándose a lo largo de la obra de García Lorca ${ }^{4}$. En España, donde "un muerto es más muerto... que en cualquiera otra parte del mundo", donde "el que quiere saltar al sueño, se hiere los pies con un filo de navaja barbera", se convierte en símbolo.

Es obvio el sentido del metal como arma. Pero García Lorca no se contenta con mostrarnos esta vinculación, sino que clasifica los metales. En el "Diálogo del Amargo" (IV, 139 y 141) dice el Jinete -la imagen del jinete está siempre ligada a la muerte ${ }^{6}$ : "Los cu-

4 ¿Quién dejará de ver en estos versos el anuncio del "alfiler que bucea / hasta encontrar las raicillas del grito". "“Asesinato", en Poeta en Nueva York: VII, 34), o del cuchillo (Bodas de sangre: I, 135) que penetra "por las carnes asombradas, / y que se para en el sitio / donde tiembla enmarañada / la oscura raíz del grito"?

" "Las nanas infantiles". (VII, 121 ). Véase también "Teoría y juego del duende" (VII, 148): “Un muerto en España está más vivo como muerto que en ningún sitio del mundo: hiere su perfil como el filo de una navaja barbera".

"En Garcia Lorca el jinete es, ya la muerte misma ("Diálogo del Amargo"), 
chillos de oro se van solos al corazón. Los de plata cortan el cuello como una brizna de hierba... Los otros cuchillos no sirven. Los otros cuchillos son blandos y se asustan de la sangre. Los que nosotros vendemos son fríos". A metal más precioso, muerte más aguda. Desde este momento la plata, a veces el oro $^{7}$, utilizados ya sin relación directa con el instrumento que hiere - puñal, cuchillo, navaja-, van a adquirir el valor de punzantes y dolorosos símbolos de la muerte ${ }^{8}$.

Aunque en el Romancero gitano reluzcan como peces "las navajas de Albacete" ("Reyerta": IV, 16), aunque el metal en su forma más patente aparezca todavía, deja aquí de ser básico. En el Romancero, como en la obra de muchos otros poetas modernos, García Lorca desarraiga sus metáforas, las arranca de su referencia inmediata a algo concreto. El metal del cuchillo se sustituye ahora por los "ojos de fría plata" ("Romance sonámbulo": IV, 18), los "senos de duro estaño" ("Romance de la luna luna": IV, 11 ). Y la metáfora metalmuerte se extiende a más amplias regiones poéticas. Antes del $R o$ mancero, el metal tenía la forma particular del cuchillo; ahora, la muerte del individuo entraña una como crispación metálica de cuanto le rodea. En el "Romance sonámbulo" ella, la Gitana - "verde carne, pelo verde, / con ojos de fría plata"-, sueña desde su baranda Pero la fría plata de sus ojos indica ya que está muerta: "las cosas la están mirando / y ella no puede mirarlas". En el drama de la muerte se acera el campo, se erizan las plantas irguiéndose en pequeños estiletes ("Romance sonámbulo": IV, 19):

ya el hombre en pos de la muerte (las "Canciones de jinete").-Sobre el tema del caballo y el jinete, cf. J. F. Cirre, "El caballo y el toro en la poesía de García Lorca", CuA, XI, 1952, núm. 6, págs. 231-245.

"En el "Diálogo del Amargo" el oro tiene una cualidad mortal e hiriente que no siempre tiene el oro en García Lorca. A veces el oro posee características puramente decorativas ("Cuatro baladas amarillas", en Primeras canciones: II, 144); y aun cuando en muchos casos el oro sea símbolo de la muerte, no lo es en el mismo sentido continuamente agresivo de la plata. En Asi que pasen cinco años el oro es mortal, pero pastoso: "El poeta Virgilio construyó una mosca de oro y murieron todas las moscas que envenenaban el aire de Nápoles. Ahí dentro, en el circo, hay oro blando, suficiente para hacer una estatua del mismo tamaño... que usted" (VI, 85). Don Perlimplín, al suicidarse frente a Belisa, le dice: "Tu marido acaba de matarme con este puñal de esmeraldas" (VI, 182). Muchas veces el símbolo del puñal se alía al del vidrio, del cristal o de la piedra preciosa.

${ }^{s}$ Ésta es una característica del Romancero. No es, sin embargo, totalmente nueva dentro de la obra de García Lorca. Ya en la "Balada de un día de julio" la campana podía identificarse con símbolos mortales.

- Parece que al escribir el "Romance sonámbulo" García Lorca pensaba precisamente en una simbolización de Granada. Estas palabras del poeta a Ana María Dalí parecen confirmarle: "Como hace buen tiempo, las señoritas de Granada se suben a los miradores encalados para ver las montañas y no ver el mar" (ANA María DaLí, Salvador Dali visto por su hermana, Barcelona, 1949, pág. 115). 
La higuera frota su viento con la lija de sus ramas, y el monte, gato garduño, eriza sus pitas agrias.

Algunas imágenes que en libros anteriores tenían relación con la muerte se conectan aquí con ella de manera más precisa. El verde, muchas veces color agresivo ${ }^{10}$, es en el Romancero el verde violento de las "pitas agrias". En "Reyerta" (IV, 16) habla el poeta del "agrio verde". Y si el verde es agrio y agresivo", es también frío ("las estrellas / clavan puñales al río / verdoso y frío", dice en "Paisaje", Libro de poemas: II, 71), frío como el metal ${ }^{12}$. Más frecuente que la referencia al verde es la referencia a la luna unida a la muerte ${ }^{13}$. "La luna le ha comprado / pinturas a la muerte”, decía García Lorca en uno de sus poemas tempranos ("La luna y la muerte", en Libro de poemas: II, 110); y en "Dos lunas de tarde" (Canciones: II, 189): "La luna está muerta, muerta". En otro poema de 1919 la luna afilaba ya su muerte ("La luna tiene dientes de marfil": II, 110). En el Romancero gitano queda establecida la relación luna-metal-muer$\mathrm{te}^{14}$. La luna "enseña, lúbrica y pura, / sus senos de duro estaño" ("Romance de la luna luna": IV, 11). Y en el mismo poema la luna conduce por el cielo al niño muerto:

Por el cielo va la luna con un niño de la mano.

Sólido, frío, el metal se extiende a todo aquello que participa de calidades pétreas: lo duro y lo helado. En el "Romance del em-

10 Para el estudio de los colores en García Lorca véase J. L. Flecniakoska, L'univers poétique de Federico Garcia Lorca, Bordeaux-Paris, 1952. El autor analiza el verde como "símbolo de amarga fatalidad" (págs. $5^{\circ}$ y sigs.). El verde no es siempre en García Lorca un color que indique la muerte. En algunas canciones ("Cuatro baladas amarillas"), el verde es decorativo: "En lo alto de aquel monte / hay un arbolito verde. / Pastor que vas, / pastor que vienes" (II, 143). Pero las más veces es color agresivo y se asocia con la muerte: "Tus tristezas son bellas, / mar de espasmos gloriosos. / Mas hoy en vez de estrellas / tienes pulpos verdosos" ("Mar", en Libro de poemas: II, 122).

${ }^{11}$ Véanse más ejemplos en J. L. Flecniakoska, loc. cit.

1: Cif. Flecniakoska, pág. 52: “... de ce vert froid, de ce poison vert qui contamine ce qui est vert par nature, lo verde, et devient sinistre en tant que vert ..."

${ }^{13}$ Véase también Flecniakoska, págs. 54 y sigs.

14 Véase el monólogo de la luna en Bodas de sangre (I, 108-109): "La luna deja un cuchillo / abandonado en el aire, / que siendo acecho de plomo / quiere ser dolor de sangre..."; y unos versos más adelante: "TTengo frío! Mis cenizas / de soñolientos metales, / buscan la cresta del fuego / por los montes y las calles”. Convertida en puñal, dice la luna: "iQue quiero entrar en un pecho / para poder calentarme!", tal como los cuchillos del Jinete ("Diálogo del Amargo": IV, 141) "entran buscando el sitio de más calor y allí se paran". 
plazado" (IV, 48) los ojos del condenado a muerte "miran un norte / de metales y peñascos" donde su "cuerpo sin venas / consulta naipes helados"15. El juego de la vida acaba en el hielo definitivo de este sólido muro de metal-peñasco. Y el "emplazado" ya sólo espera que todo lo que tiene aristas mortales ("cicutas", "ortigas") penetre en su carne ${ }^{16}$.

Síntesis y precisión de sus obras anteriores, el Romancero gitano muestra decisivamente ampliada la imagen metálica que venía predominando desde los primeros poemas de García Lorca. En Poeta en Nueva York ha de buscarse la más completa y aguda expresión de esta imagen.

"Asesinado por el cielo, / entre las formas que van hacia la sierpe / y las formas que buscan el cristal", anegado por la muerte, el poeta contempla "el árbol de muñones que no canta", los "animalitos de cabeza rota", la "mariposa ahogada en el tintero" ("Asesinado por el cielo": VII, 11 ). En Poeta en Nueva York la ciudad entera se eriza de símbolos mortales.

A los metales nobles de los libros anteriores (plata, oro) vienen a sustituirse los metales que sugieren usos industriales (aluminio, níquel) y hasta el objeto industrial mismo (alambre). "Nueva York de alambre y de muerte", dice en la "Oda a Walt Whitman" (VII, 72). El poeta increpa a la ciudad. Pero no sólo percibe la aridez agresiva de los metales, no permanece simplemente "en espera de la bala" "Grito hacia Roma": VII, 70), sustituto del puñal: los metales mismos se corroen y se oxidan y nos muestran sus ríspidas aristas ("Danza de la muerte": VII, 27):

Era el momento de las cosas secas,

de la espiga en el ojo y el gato laminado, del óxido de hierro de los grandes puentes.

La arista misma del metal penetra en las cosas: lo "seco", la "espiga en el ojo"17. Y si aquí, como en "Santa Lucía y San Lázaro", apa-

${ }^{15}$ Los naipes suelen ser el símbolo de la muerte o del juego de la vida, por ejemplo en "Reyerta" (Romancero gitano: IV, 16); en Asi que pasen cinco años, cuando va a morir el Joven, "en los anaqueles de la biblioteca aparece un as de caur iluminado. El Jugador 1 ọ saca una pistola y dispara sin ruido con una flecha. El as de cœur desaparece y el joven se lleva las manos al corazón" (VI, 108-109).

${ }^{16}$ Hay en la poesía de García Lorca una serie de vegetales que se alían con el mineral y con la piedra. García Lorca hace notar esta relación: "No es casualidad todo el arte español ligado con nuestra tierra, lleno de cardos y piedras definitivas" ("Teoría y juego del duende": VII, 149).

${ }^{17}$ No siempre tiene la espiga un sentido agresivo. En Poeta en Nueva York la espiga llega a representar la única esperanza de salvación para esta "América 
rece la imagen de lo vivo convertido en lámina metálica ${ }^{18}$, en otros versos aparece la máquina viva, "automóviles cubiertos de dientes" ("El rey de Harlem": VII, 24), "monedas en enjambres furiosos" ("La aurora": VII, 41). Total metamorfosis: la vida es metálica y el metal adquiere formas vivas para herir con mayor sadismo. Entre las imágenes significativas dentro de Poeta en Nueva York está la de la moneda. Si en el Romancero gitano la moneda tenía un sentido de vida - de eternización-dentro de la muerte ("Tres golpes de sangre tuvo / y se murió de perfil. / Viva moneda que nunca / se volverá a repetir": "Muerte de Antoñito el Camborio", IV, 43), ahora la moneda adquiere un sentido necesariamente mortal: "y el director del banco observaba el manómetro / que mide el cruel silencio de la moneda" ("Danza de la muerte": VII, 28). La moneda adquiere así un nuevo sentido ${ }^{19}$ : es la muerte del espíritu, porque supone la destrucción de la inocencia. En esta fiesta de los "enjambres furiosos" es el niño el que muere, más herido y maltratado por la ciudad que por las canciones de cuna españolas (cf. "Las nanas infantiles", VII, 1 $17-139)$ :

De la esfinge a la caja de caudales hay un hilo tenso que atraviesa el corazón de todos los niños pobres.

o, con mayor exactitud, en otro poema ("La aurora": VII, 41):

A veces las monedas en enjambres furiosos táladran y devoran abandonados niños.

La agresividad, la perforación de la carne por el metal se hace en Poeta en Nueva York más incisiva. A una muerte que en el Romancero miraba de frente, sucede una muerte agazapada que acecha secretamente. A puñales, cuchillos y navajas barberas corresponden aquí los alambres, las agujas, los alfileres, los hilos tensos. Dos poemas, uno de 1921 y el otro de 1930, anticipan esta correspondencia entre los dos grupos de imágenes. A los trece versos de "Sorpresa" (Poema del cante jondo: IV, 85) corresponden los trece de "Asesinato" (Poeta en Nueva York: VII, 34):

impúdica y salvaje" que el poeta describe en la "Oda a Walt Whitman" (VII, 76 ): Una danza de muros agita las praderas y América se anega de máquinas y llanto. Quiero que el aire fuerte de la noche más honda quite flores y letras del arco donde duermes y un niño negro anuncie a los blancos del oro la llegada del reino de la espiga.

18 "Cuando murió [San Lázaro], estaba duro y laminado como un pan de plata" ("Santa Lucía y .San Lázaro": VII, 165).

18 La moneda tiene también, como puede verse por los ejemplos dados, un sentido social. 
Múerto se quedó en la calle con un puñal en el pecho. No lo conocía nadie.

- ¿Cómo temblaba el farol!

Madre.

¿Cómo temblaba el farolito de la calle!

Era madrugada. Nadie pudo asomarse a sus ojos abiertos al duro aire.

Que muerto se quedó en la calle que con un puñal en el pecho y que no lo conocía nadie.
- ¿Cómo fué?

-Una grieta en la mejilla.

¡Eso es todo!

Una uña que aprieta el tallo.

Un alfiler que bucea

hasta encontrar las raicillas del

$\mathrm{Y}$ el mar deja de moverse [grito.

${ }_{-}^{-}$CCómo, cómo fué?

-Así.

- iDéjame! ¿De esa manera?

- Sí.

El corazón salió solo.

- iAy, ay de mi!

El puñal de Sorpresa se convierte en la "grieta en la mejilla", el "alfiler que bucea", la "uña que aprieta el tallo" de "Asesinato"; el temblor del farol se traduce en el frenesí de los versos que el poeta subraya; al ritmo sonoro y claro se contrapone el acerado ritmo de preguntas y respuestas, breves y tajantes. Un último verso andaluz sitúa "Asesinato" en la tradición de García Lorca. Como los "siete ayes clavados" de "Camino" (Poema del cante jondo: IV, 101), se clavan aquí los "ayes" del alfiler y de la uña 20 .

Estamos en el centro mismo de la metáfora metálica con "la espina del puñal" ("El rey de Harlem": VII, 22), con "las muchedumbres en el alfiler" ("Luna y panorama de los insectos": VII, 6o), con el azúcar que "puñalitos sueña en su vigilia" ("Muerte": VII, 53). La ciudad entera está constituída por estos diminutos y crueles mecanismos. Y hay un "sabor a metal acabado" en la luz misma"21, en esta luz que se afila como una espada ("Danza de la muerte": VII, 27):

Era la gran reunión de los animales muertos, traspasados por las espadas de la luz.

En el Llanto por Ignacio Sánchez Mejias con sus cuatro movimientos dramáticos se nos da el García Lorca más pleno y maduro. A los clásicos versos reminiscentes de Jorge Manrique ("iQué gran torero en la plaza! / ¿Qué buen serrano en la sierra! / ¿Qué blando con las espigas! / ¿Qué duro con las espuelas!”, IV, 156) siguen los

${ }^{20}$ Esta agresividad no es privativa de Poeta en Nueva York, aunque en este libro constituya la tónica. En la "Oda al Santísimo Sacramento del altar", publicada en 1928, antes del viaje del poeta a Nueva York, García Lorca escribía estos versos: "La gillette descansaba sobre los tocadores / con su afán impaciente de cuello seccionado" (VI, 155).

${ }^{21}$ En Mariana Pineda adquiere la luz el mismo sentido cuando canta Mariana: "¡Y esta noche que no llega! / ¡Noche temida y soñada; / que me hicres ya de lejos / con larguísimas espadas!" (V, 148). 
alejandrinos reminiscentes del Cantar de mio Cid: "Ya está sobre la piedra Ignacio el bien nacido..."

En el primer movimiento, mientras el estribillo de los sones de bordón ("a las cinco de la tarde") da las campanadas definitivas de la hora mortal, una nueva imagen, tres veces repetida, viene a imponerse en el poema ("La cogida y la muerte": IV, $15^{1-1} 5^{2}$ ):

Y un muslo con un asta desolada ...

¡Y el toro solo corazón arriba!...

El toro ya mugía por su frente.

El cuerno del toro toma el lugar del puñal. A la metáfora metalcuchillo-muerte se añade ahora el asta, símbolo de la agresividad del toro-muerte: el cuerpo del torero se ve invadido por el "asta desolada" y llega la muerte cuando el toro "mugía por su frente".

A lo agresivo de la muerte (puñal, alfiler, asta) se suma la muerte representada otra vez por lo sólido y lo pétreo, lo mineral, lo rocoso: "Ya está sobre la piedra Ignacio el bien nacido". Ignacio, en "Cuerpo presente", está, como el "emplazado", frente a metales y peñascos. La piedra es la solidez absoluta de lo inanimado. Y aquí, en el Llanto, la piedra está representada por la plaza de toros ("plazas y plazas y otras plazas sin muros", IV, 158). Así se amplía la metáfora de la muerte hasta representar este hecho único que es España. El toro y la plaza son los símbolos de la muerte española y el nombre del torero crece hasta ser el símbolo de España misma. "España es el único país donde la muerte es el espectáculo nacional, donde la muer-; te toca largos clarines a la llegada de las primaveras" ("Teoría y juego del duende": VII, 154). Y es en España también donde "todo tiene un último valor metálico de muerte. La cuchilla y la rueda.. del carro y la navaja y las barbas pinchonas de los pastores y la luna pelada y la mosca y las alacenas húmedas y los derribos y los santos cubiertos de encaje y la cal y la línea hiriente de aleros y miradores tienen en España diminutas hierbas de muerte" (ibid., 149).

El toro que mata a Sánchez Mejías es como "los toros de Guisando, / casi muerte y casi piedra", que mugen "como dos siglos" ("La sangre derramada": IV, 155). Por eso el Llanto constituye la más extrema ampliación de la imagen que hemos venido analizando. La fantasía sobre la muerte viene a desembocar en este símbolo definitivamente español del toro, del torero y de la plaza; del destino, del hombre y del "blanco muro de España".

México, D. F-

Ramón XIRau 